\title{
Pengembangan Model Latihan Kombinasi Berbasis Media Flip Book Maker Pada Pemain Sepak Bola Tingkat Intermediate
}

Januar Abdilah Santoso

Pendidikan Olahraga, Fakultas Keguruan dan Ilmu Pendidikan, Universitas Muhammadiyah Kalimantan

Timur, Jas970@umkt.ac.id

\section{Jeane Betty Kurnia Jusuf}

Pendidikan Olahraga, Fakultas Keguruan dan Ilmu Pendidikan, Universitas Muhammadiyah Kalimantan

Timur, Jbk567@umkt.ac.id

\section{Rudiman}

Pendidikan Olahraga, Fakultas Keguruan dan Ilmu Pendidikan, Universitas Muhammadiyah Kalimantan Timur,Rud959@umkt.ac.id

\section{Indiana Nawang Yuli Safitri}

Pendidikan Olahraga, Fakultas Keguruan dan Ilmu Pendidikan, Universitas Muhammadiyah Kalimantan Timur, indiananawang5@gmail.com

\section{Wasiatul Aqmaliah}

Pendidikan Olahraga, Fakultas Keguruan dan Ilmu Pendidikan, Universitas Muhammadiyah Kalimantan Timur,wasiatul1506@gmail.com

\section{Julianur}

Pendidikan Olahraga, Fakultas Keguruan dan Ilmu Pendidikan, Universitas Muhammadiyah Kalimantan Timur, julianur@umkt.ac.id

\section{Nanda Alfian Mahardhika}

Pendidikan Olahraga, Fakultas Keguruan dan Ilmu Pendidikan, Universitas Muhammadiyah Kalimantan Timur, nam791@umkt.ac.id

\begin{abstract}
Abstrak
Tujuan pengembangan model latihan kombinasi berbasis media flip book maker pada pemain sepak bola tingkat intermediate ini adalah untuk menghasilkan produk model Latihan drill yang efektif untuk meningkatkan kemampuan teknik sepak bola. Penelitian pengembangan (research and development) adalah jenis penelitian ini. Adapun 10 tahap tersebut di jelaskan dalam 4 tahapan, yaitu Studi pendahuluan, Pengembangan Produk, Pelaksanaan uji coba, dan Uji efektivitas produk dengan eksperimen. Teknik pengumpulan data berupa: wawancara, untuk data studi pendahuluan, questionair uji ahli dan subjek penelitian, tes untuk keterampilan teknik dasar sepak bolanya, dan observasi data catatan lapangan dan evaluasi produk. Teknik analisis data yang digunakan ada dua yaitu pendekatan kualitatif dan pendekatan kuantitatif. Dari hasil penelitian dapat diketahui bahwa pada tes akhir terlihat rata-rata (mean) untuk kelompok kontrol adalah 210,67 dan untuk kelompok sampel adalah 222,08, artinya bahwa rata-rata nilai Kemampuan tekhnik dasar kelompok sampel lebih tinggi daripada rata-rata nilai kemampuan kelompok kontrol pada saat test akhir. Hasil Uji T menunjukkan sig 0.226 atau $<0.05$, maka dapat disimpulkan tidak ada perbedaan kemampuan yang signifikan antara hasil kemampuan kelompok kontrol dengan kelompok sampel pada test akhir.
\end{abstract}

Kata Kunci : pengembangan, latihan, flip book maker, sepak bola 


\section{PENDAHULUAN}

Salah satu cabang olahraga yang popular diindonesia saat ini ialah sepak bola . seperti hal nya olahraga lain, Memahamkan siswa/pemain terhadap instruksi keinginan dari pelatih terhdap latihan yang direncanakan bukanlah hal yang mudah, saat ini. Umumnya pelatih menggunakan papan strategi, teknik komando, dan tidak memanfaatkan media audiovisual maupun media elektronik yang sudah menjadi kebutuhan di era sekarang. Dwiyogo (2008:334) menjeaskan tentang media audiovisual adalah "media pandang dengar dan suara, seperti lazimnya televisi, film bersuara dan video". Jadi penggunaan media audiovisual dalam pembelajaran tentu saja dapat sangat membantu dalam memberikan pemahaman terhadap atlet /siswa, karna dapat memproyeksikan keinginan pelatih secara utuh dalam rencana-rencana yang akan dilakukan.

Sudah pasti materi yang disusun oleh pelatih profesional tidak sedikit, kemampuan siswa/atlet dalam menyerap materi yang diberikan tentu saja berebeda. Dan merupakan tugas dari pelatih/pengajarlah untuk membuat jarak perbedaan ini semakin kecil, salah satunya menggunakan kemajuan tekhnologi. Dengan berkembangnya teknologi saat ini media pembelajaran sudah banyak yang menggunakan media gadget dalam penyampaiannya. Kemampuan yang dahulu hanya dapat dilakukan menggunakan computer, kini sudah dapat diakses melalui teknologi ponsel-ponsel pintar yang sudah menjadi candu bagi kalangan milenial. Memanfaatkan fenomena ini perlu dibuat sebuah buku elektronik yang mempermudah siswa/atlet menjalankan latihan yang diinginkan pelatih dengan terdapat fasilitas audiovisual didalamnya untuk mempermudah siswa/atlet belajar.

Media flip book maker ini dapat membantu untuk mewujudkan hal tersebut. Seperti beberapa media modern yang lainnya, kebutuhan akan narasi, gambar mauopun video untuk memperjelas proses latihan, media flip book maker dapat memenuhi semua kebutuhan tersebut, selain itu software ini dapat diakses melalui laptop maupun handphone yang selama ini menjadi kebutuhan sehari-hari pada generasi muda. Bagaikan tugas sekolah, atlet dapat belajar dan mengulangi pembelajaran modelmodel latihannya sebelum maupun sesudah latihan, yang tentu saja dapat menjadi sarana belajar maupun latihan mandiri atlet.

Atas dasar latar belakang di atas, pelatih harus selalu terbuka terhadap perkembangan jaman dalam memilih model latihan-latihan yang efektif, efisien. Dengan adanya model latihan sepak bola berbasis flip book maker diharapkan menjadi media yang mambantu pelatih menyampaikan materi dan membantu pemain dalam memahami instruksi pelatih.

Latar belakang diatas menjadi dasar kuat dilakukan penelitian dengan judul "pengembangan model latihan kombinasi berbasis media flip book maker pada pemain sepak bola tingkat intermediate".

\section{METODE}

Penelitian pengembangan (research and development) adalah jenis penelitian ini. Degeng (2002:1) menyimpulkan arti dari penelitian pengembangan yaitu "penelitian ilmiah yang menelaah suatu teori, model, konsep, atau prinsip, dan menggunakan hasil telaah untuk mengembangkan suatu produk". Model pengembangan model latihan drill adalah model Borg and Gall didasari adanya kesamaan terhadap tujuan yang direncanakan peneliti. penelitian pengembangan (research and development) Borg and Gall yang terdiri dari 10 tahap. Adapun 10 tahap tersebut akan di jelaskan dalam 4 tahapan yang akan dipakai peneliti, tahapan tersebut adalah penelitian ini adalah sebagai berikut:

1. Tahap Pertama (Studi pendahuluan)

2. Tahap Kedua (Pengembangan Produk)

3. Tahap ketiga (Pelaksanaan uji coba) 
4. Tahap Keempat (Uji efektivitas produk dengan eksperimen)

\section{a. Teknik Pengumpulan Data}

Fokus dalam pengumpulan data terdiri dari Kondisi awal, pennilaian ahli, uji coba kelompok, dan hasil dari uji efektifitas. Dengan tekhnik yang dijelaskan sebagai berikut:

1) Teknik wawancara dipergunakan untuk mengumpulkan data studi pendahuluan

2) Teknik questionair diberikan pada para ahli dan pengguna produk dan mengukur penilaian kelayakan mereka terhadap produk yang dibuat

3) Teknik tes berisi tentang in intrumentinstrument untuk mengukur keterampilan teknik Passing- olah bola -Shooting sepak bola pada pemain intermediet.

4) Teknik observasi digunakan untuk melihat dan mengumpulkan data catatan lapangan terhadap keterlaksanaan dan penerapan penelitian (model latihan).

\section{b. Teknik Analisis Data}

Pendekatan dalam analisis data dalam penelitian ini terdiriatas pendekatan kualitatif dan kuantitatif. Kedua Pendekatan dipilih dikarenakan dapat menyajikan data secara lebih jelas dalam penelitian ini.

\section{Pendekatan kualitatif}

Yaitu dengan cara: (1) reduksi data, (2) penyajian data, dan (3) penarikan kesimpulan. Melalui cara yang sistemis, reduksi data akan disajikan secara gamblang sehingga dapat ditarik kesimpulan yang sesuai dengan kondisi di lapangan.

\section{Pendekatan kuantitatif}

Pengumpulan data melalui questioner ahli sepak bola maupun atlet, dan hasil dari data pre tes - post test pada saat uji efektifitas produk nantinya digunakan untuk pendekatian kuantitaif yang terdiri dari:

\section{a. Pengujian data}
1) Uji Normalitas distribusi frekuensi
2) Uji Homogenitas variansi populasi

b. Analisis data

1) Analisis data questionair ahli sepak bola dan questionair atlit.

2) T-SCORE

3) Paired Sampel T-Test

4) ANOVA

Secara sederhana alur penyusunan produk penelitian dapat terlihat pada gambar dibawah ini:

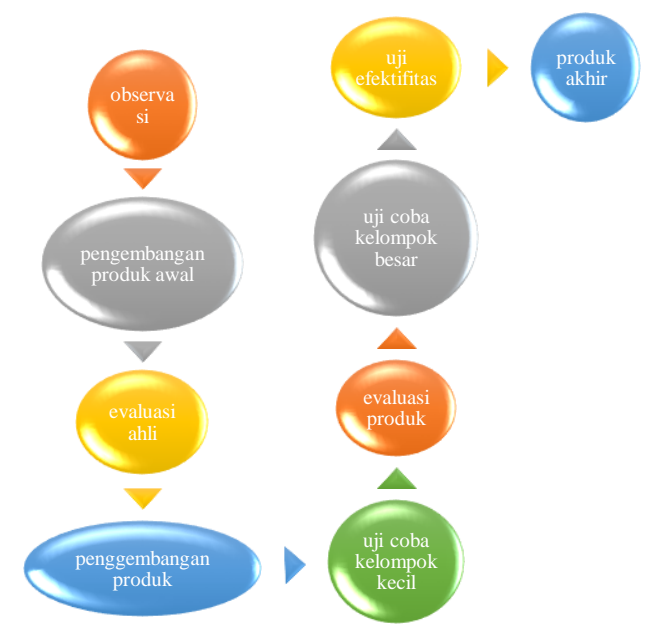

Gambar 1: alur penyusunan produk penelitian

\section{HASIL DAN PEMBAHASAN}

Pembahasan hasil penelitian memberikan gambaran secara lebih rinci dan jelas terhadap analisis data yang yang dilakukan dalam beberapa tahapan.

Terdapat kesimpulan analisis yang terbagi dalam beberapa tahapan sesuai prosedur penelitian pengembangan, berikut penjelasannya:

\section{1) Tahap Pertama (Studi Pendahuluan)}

Dalam penelitian ini Studi Pendahuluan menjadi tahapan yang wajib dilakukan. Penelitian ini sebagai jembatan penghubung yang tercipta dari penelitian pendidikan dan prakten dalam pendidikan. Degeng (2002:1) menyatakan penelitian pengembangan merupakan "penelitian ilmiah yang menelaah suatu teori, model, konsep, atau prinsip, dan menggunakan hasil telah untuk mengembangkan suatu produk". Penelitian pengembangan didasari pada kebutuhan terhadap pemecahan 
masalah yang dimiliki dan pemcahan tersebut dilakukan menggunakan sebuah produk terentu meskipun bukanlah produk yang baru ada.

Studi pendahuluan menjadi awal tahapan mengidentifikasi perasalahan yang dihadapi dalam penelitian. Menurut Arikunto (2009:26) "Studi pendahuluan adalah kegiatan yang dilakukan oleh calon peneliti untuk mengadakan pengumpulan data sementara demi pastinya langkah yang akan dilalui".

Masalah yang ada akan diungkapkan dalam tahapan studi pendahuluan dan disusun ruang lingkup terhadap pembatasan masalah, kemudian ruang lingkup yang terbentuk segera disusun rumusan masalah menggunakan teoriteori yang dimiliki menggunakan dua kegitan yaitu analisis kebutuhan, analisis hasil kebutuhan dan penyusunan pembuatan draft produk.

\section{a. Analisis Kebutuhan}

Langkah analisis kebutuhan diperlukan untuk mendapatkan solusi dari masalah yang dihadapi. Menurut Borg dan Gall (1983:753) "menyimpulkan bahwa analisis kebutuhan merupakan pengumpulan informasi awal terhadap perbedaan kondisi yang ada dilapangan dan kondisi yang diinginkan, untuk kebutuhan pemecahan masalah yang ada".

Informasi awal diperlukan sebagai penentu langkah berikutnya untuk mengatasi masalah yang diadapi yang merupakan perhatian inti dari penelitian yang dilakukan. Tahap ini berfungsi sebagai cara mengetahui kebutuhan materi serta sebagai bentuk kondisi yang nyata dan bahan kajian penelitian.

Menurut Winarno (2011:9) “masalah merupakan kesenjangan antara harapan dengan kenyataan, kesenjangan antara teori dan praktik yang memerlukan jawaban, penjelasan atau pemecahan". Informasi awal yang berhasil dikumpulkan tentu akan menunjukkan kondisi sesunggunhya dilapangan. Hasil yang didapat akan memunculkan fokus utama pengamatan maupun solusi pemecahan masalah yang dibutuhkan untuk memperkecil antara kenyataan dengan harapan dari penelitian.

Observasi, wawancara maupun test dapat digunakan dalam tahapan pengumpulan informasi awal sebagai bentuk instrument dari penelitian. Dan dengan demikian akan diperoleh kesimpulan dalam analisis kebutuhan itu sendiri.

Studi pendahuluan dilakukan pada pemain sepak bola di Kota Samarinda yang difokuskan pada keterampilan teknik dasar sepak bola pada kelompok pemain tingkat intermediate. Wawancara bebas terhadap pemain dipilih sebagai instrument pada Studi pendahuluan. wawancara bebas dilakukan kepada para pelatih sepak bola di Provinsi Kalimantan timur.

\section{b. Analisis Hasil Analisis Kebutuhan}

Peneliti menentukan wawancara dilakukan kepada para pelatih tim sepak bola yang membina pemain tingkat intermediate karena merupakan sosok yang paling mengerti kondisi kesulitan yang muncul dilapangan selama bertahun-tahun melalui ilmu empirisnya. "Wawancara adalah sebuah dialog yang dilakukan oleh pewawancara dengan yang diwawancarai untuk memperoleh data berupa informasi dari orang yang diwawancarai (interviewer)" (Winarno, 2011:100). Hasil yang diperoleh dari wawancara bebas yang dilakukan pada beberapa pelatih sepak bola di kalimantan timur. Wawancara bebas tidak dilakukan menggunakan pedoman tertentu.

Pengumpulan informasi terpusat pada kemampuan ktrampilan tekhnik dasar sepak bola dan diawali oleh studi pendahuluan, dan didapatkan hasil penguasaan keterampilan teknik dasar sepak bola tingkat intermediate yang masih kurang baik. 
Dari hasil wawancara bebas pun tekhnik dasar maupun kemampuan fisik masih menjadi perhatian utama bagi para pelatih karena merupakan masih sangat lemah di tingkat intermediate.

Dari hasil observasi yang dilakukan spesifikasi latihan yang ditujukan untuk meningkatkan ketrampilan dasar masih kurang variasi dan banyak terfokus pada visi bermain. Sedangkan dari pihak pelatih beralasan masih buruknya tekhnik dasar dan kondisi fisik pemainnya disebabkan banyaknya aktifitas dirumah mengharuskan pemain tidak bisa mengikuti pelatihan secara rutin. Sehingga materi tidak tersampaikan secara runtut sehingga menyebabkan kesulitan memperoleh kemajuan sesuai dengan harapan pelatih.

\section{c. Menyusun dan Pembuatan Draft Pengembangan Produk Berbasis Media Flip Book Maker}

Terdiri dari tahap-tahap yang telah ditentukan sesuai prosedur pengambangan. Berikut penjelasan dari tiap tahap tersebut:

\section{Pengkajian Teoritis}

Kajian teori diperlukan untuk lebih mendalami meteri secara ilmiah, serta mengkaji lebih jauh kebutuhan akan produk dalam penelitian. Kajian teori dikumpulkan sebagai dasar ilmiah maupun ilmu empiris yang diperlukan dalam penyusunan produk yang dituukan untuk mengatassi masalah yang ditemukan dilapangan. Produk nantinya diharapkan menciptakan solusi yang tengah dihadapi pada fase studi pendahuluan. Sesuai dengan judul penelitian dan permasalahan yang telah dikeukakaknsebelumnya, maka kajian teori yang dianggap relevan meliputi teori-teori yang berkaitan tentang:

a. Teori latihan, yang meliputi teori program latihan dan latihan fisik

b. Teori sepak bola, termasuk didalamnya membahas Teori teknik dasar sepak bola yang terdidi dari controlling passing, shooting dan dribbling.

c. Teori kebutuhan pemain sepak bola.

d. Teori Model Pengembangan

Logika berfikir empiris digunakan untuk pemilian teori yang akan disusun dalam tahap ini. Penyusunan alur penyusunan dibuat selogis mungkin dan disusun pemnggunakan penalaran deduktif dalam penjabarannya. Menurut (Hakim, dkk, 2012:5) "penalaran deduksi adalah cara berpikir dimana dari pernyataan bersifat umum ditarik kesimpulan bersifat khusus". Penalaran ini dirasa paling relevan terhadap proedur penelitian dan paling dapat menunjukkan alur berfikir yang paling logis diantara yang lain

\section{Penyusunan dan Pengembangan Produk Awal}

Model latihan kombinasi berbasis media flip book maker pada pemain sepak bola tingkat intermediate menjadi produk yang dirancang dan diharapkan mengatasi masalah yang menjadi fokus utama penelitian. Ateri produk ditentukan oleh studi pendahuluan dan kajian teori yang sudah dilakukan sebelumnya. materi tersebut kemudian disusun menjadi draft awal dalam pembuatan produk yang direncanakan.

Produk yang direncanakan tersebut terdiri dari model latihan kombinasi berbasis media flip book maker pemain sepak bola tingkat intermediate yang bertujuan dapat meningkatkan keterampilan teknik dasar sepak bola kelompok intermediet. Dari kajian teori yang sudah dilaksanakan diputuskan susunan produk membahas materi sebagai berikut

a) Peraturan perwasitan

b) Formasi dalam sepak bola

c) Model latihan kombinasi teknik dasar sepak bola passing, control, dribble dan shooting. 


\section{Pembuatan Video Latihan Teknik dasar Sepak bola}

Pembuatan video latihan diperuntukkan sebagai tambahan media suaya instruksi lebih jelas dan mudah dimengerti. Pembuatan video dilakukan oleh peneliti sebgai cameraman yang dan Menggunakan kamera Hp dikarenakan keterbatasan alat.

\section{Penyusunan Produk menggunakan Media Flip Book Maker}

Setealah produk tercipta setelah melewati tahapan penyusunan materi dalam bentuk ebook dan video yang sdah terkumpul, maka tahap selanjutnya ialah memasukkan semua materi kedalam software supaya dapat diakses oleh pelatih maupun pemain melalui handphone maupun komputer guna mempermudah mereka dalam belajar meskipun secara mandiri serta mempermudah pelatih dalam memberikan instruksi yang makin rumit sesuai dengan tahapan intermediet.

\section{Uji Coba Produk Pengembangan}

Tahapan selanjutnya ialah uji coba produk dengan maksud mendapatkan hasil penilaian kelayakan produk dilapangan setelah melalui penilaian kelayakan oleh ahli, kelompok kecil, kelompok besar yang kemudian akan dilihat pengaruh produk terhadap pemain sepak bola kelompok intermediet melalui uji efektifitas. Berikut penjelasan terhadap tahapan-tahapan dalam uji coba produk.

\section{a. Uji Coba Ahli (Expert Judgment)}

Tahap ini diperlukan untuk mendapatkan saran maupun tanggapan kelayakan dari ahli yang sudah diakui. Kesempurnaan produk diharapkan tercipta dari masukan dan penilaian ahli. Menurut Borg dan Gall (1983:781) "uji coba dengan evaluasi pakar adalah untuk mengetahui rancangan produk awal dapat di uji coba lapangan".

Produk awal akan ditunuukkan kepada para ahli yang terdiri dari ahli akademisi serta ahli praktisi. Penentuan ahli praktisi maupun akadeisi dilihat dari pngalaman menekuni dunia olahraga khususnya sepak bola yang sudah lama dan diakui melalui sertifikat resmi.

Nilai kelayakan diperoleh dari tanggapan para ahli dan juga melalui uji validitas sehingga produk benar-benar memiliki kesempurnaan. Uji validitas sebagai bentuk penilaian kesesuaian angket yang telah diberikan kepada ahli dalam menilai produk. Penilaian angket dilakukan menggunakan skala penilaian (rating scales).

Terdapat dua bentuk penilaian yang didapat dari uji evaluasi ahli yang dilakukan, hasil penilaian terdiri dari data kuantitatif dan kualitatif. untuk hasil evaluasi data kuantitatif dengan skala likert dan data kualitatif didapatkan dari jawaban akan pertanyaan yang diajukan kepada narasumber. Hasil dari ahli inilah yang nantinya akan menjadi acuan terhadap kelanjutan produk awal yang telah disusun tersebut. Dan dari hasil angket yang tealah diberikan diperoleh hasil bahwa produk awal sudah memenuhi faktor-faktor yang dianggap layak untuk dilanjutkan sesuai masukan para ahli yang ditunjuk dan dipilih.

\section{b. Uji Coba Kelompok Kecil/Terbatas}

Tahapan berikutnya yang harus dialui dalam penyusunan produk model latihan kombinasi berbasis media flip book maker pemain sepak bola tingkat intermediate ialah uji coba kelompok dalam skala yang kecil. Terkadang uji ini dikenal pula dengan uji kelompok terbatas dikarenakan kelompok subjek penelitian masih terbatas pada jumlah yang kecil. Menurut Borg dan Gall (1983:782) "tujuan dari uji coba terbatas adalah untuk mengetahui hasil produk pengembangan yang baru dalam skala yang kecil." Uji coba ini dilakukan untuk mengetahui kelayakan produk dari sisi keberterimaan, dan pelaksanaan maupun kesulitan-kesulitan yang timbul dari uji coba 
sebagai masukan dan perbaikan produk dikemudian hari. Maskan dan saran bisa saja berasal dari hasil observasi maupun dari para subjek kelompok kecil itu sendiri.

Subjek pada Uji coba kelompok kecil ini berjumlah 12 pemain yang berasal dari tim Sepak bola nahusam. Hasil pelaksanaan pada uji kelompok ini diperoleh fakta bahwa produk awal model latihan kombinasi berbasis media flip book maker pemain sepak bola tingkat intermediate dapat diuji cobakan pada uji coba selanjutnya dengan melihat hasil evaluasi tentunya.

\section{c. Revisi Produk dari Kelompok Kecil/Terbatas}

Setelah Revisi produk hasil uji coba kecil diterapkan maka uji coba kembali dilakukan namun dengan jujmlah subyek yang lebih besar sebagai bentuk tindak lanjut setelah uji coba kelompok kecil yaitu tahap uji kelompok besar. Revisi produk harus dilakukan dengan seksama untuk diterapkan pada saat pelaksanaan uji coba kelompok besar. Pelaksanaan dan manajemen waktu bisa berjalan lebih efektif. Masukan berkaitan dengan intonasi suara aat melakukan instruksi pelaksanaan produk, serta beberapa jarak alat bantu latihan yang harus diubah jaraknya.

\section{d. Uji Coba Kelompok Besar/Luas}

Uji kelompok besar merukan tahapan lanjutan dari uji kelompok kecil. Menurut Borg dan Gall (1983:783) "uji coba luas ditujukan untuk memutuskan bahwa produk pengembangan telah sesuai dan layak dengan tujuan yang ingin dicapai". Sama hal nya dengan uji kelompok kecil namun dengan skala subyek yang lebih besar, selain itu subyek yang dipilih bukanlah bagian dari subyek kelompok kecil.

Uji kelompok besar dilakukan untuk melihat kelayakan dari produk yang dibuat sebelum dilanjutkan pada uji efektifitas produk akhirnya. Diharapkan dengan adanya uji kelompok besar produk sudah siap sepenuhnya sehingga tidak menimbulkan masalah saat dilakukan uji efektifitas. Subjek pada Uji coba kelompok besar ini berjumlah 24 pemain yang terdiri dari pemain sepak bola tim Harbi. Jumlah ini dirasa cukup sebagai interprestasi tiap tim sepak bola kelompok intermediet yang pemainnya tidak lebih dari 24 pemain dalam sebuah pertandingan resmi.

Hasil uji coba kelompok besar mengatakan bahwa produk sudah dapat dilakukan pada tahap uji efektifitas namun dengan beberapa masukan yang didapat dan digunakan dalan revisi produk untuk dilakukan saat di fase uji efektifias produk.

\section{e. Revisi Produk Uji Coba Kelompok Besar/Luas}

Revisi produk tidak terlalu banyak berkat revisi saat di kelompok kecil, revisi dilakukan hanya pada area manajement waktu serta pengorganisasian pemain supaya lebih efisien dan pemain tidak teralu lama menunggu giliran. Revisi ditemukan bahwa memerlukan bola yang lebih banyak untu kelompok yang lebih besar, serta manajemen waktu yang matang.dan dari Hasil revisi menunjukkan bahwa produk pengembangan model latihan kombinasi sepak bola tingkat intermediate berbasis media flip book maker dapat diuji tingkat efektivitasnya.

\section{f. Uji Efektifitas Produk}

Tim SM Sepak bola Nahisam dan SSB Harbi menjadi tim yang dipilih untuk mengetahui tingkat efektivitas produk model latihan kombinasi sepak bola tingkat intermediate berbasis media flip book maker. Dalam uji kali ini sangat berbeda dari uji sebelumnya, pada uji ini dibuat 2 kelompok yang yang berbeda, salah satu kelompok akan diuji cobakan menggunakan produk/ kelompok sampel dan kelompok yang lain menjadi kelompok kontrol/ tidak menggunakan produk dengan tujuan mengetahui perbedaan yang diterima olh 
masing-masing kelompok. Untuk mengetaahuinya maka akan dilakukan analisis uji beda pada kelompok tersebut. Rancangan yang dipakai ialah desain eksperiment dengan pre test dan postest didalamnya.

Menurut Arikunto (2009:210) "rancangan ekperimen dengan satu macam perlakuan (pretest-posttest control group design) dilakukan dengan cara kedua kelompok diberi tes awal untuk mengukur kondisi awal, kemudian pada kelompok eksperimen diberikan perlakuan sedangkan pada kelompok pembanding tidak diberi".

Kelompok pembanding nantinya akan diberikan progam konvensional dari masingmasing klub, kemudian selama 18x pertemuan dilihat perbedaan hasil yang didapat antara kelompok sampel dan kelompok kontrol/pembanding tersebut. Hasil uji yang diambil ialah dengan menggunakan instrumen tes keterampilan, yang dalam hal ini adalah keterampilan teknik dasar pada pemain sepak bola tingkat intermediate.

Dari hasil yang diperoleh dan melalui uji analisis yang telah dilakukan, terlihat adanya perbedaan diantara kelompok eksperiment dan kelompok kontrol. Kelompok sampel/ kelompok yang menggunakan produk mengalami kenaikan nilai yang lebih tinggi secara raa-rata dibandingkan kelompok yang tidak menggunakan produk/ kelompok kontrol setelah dilakukan uji analisis. Perbandingan dilakukan antara nilai saat pre-test dan nilai saat post-test.

Berdasarkan data yang ada, kesimpulan pada hasil akhir bahwa dari rata-rata nilai kelompok sampel, produk model latihan dapat meningkatkan hasil keterampilan teknik dasar sepak bola tingkat intermediate di Kota Kalimantan timur.

Meskipun secara rata-rata produk lebih mampu meningkatkan rata-rata dari kelompok eksperimen dibandingkan metode konvensional pada kelompok kontrol, jika meliha hasil uji $\mathrm{t}$ perbedaan antar kelompok tergolong tidak signifikan atau tidak mengalami perbedaan.

\section{PENUTUP}

Pada tabel Group Statistics terlihat rata-rata (mean) untuk kelompok kontrol adalah 210,67 dan untuk kelompok sampel adalah 222,08, artinya bahwa rata-rata nilai Kemampuan tekhnik dasar kelompok sampel lebih tinggi daripada rata-rata nilai kemampuan kelompok kontrol pada saat test akhir. Hasil Uji T terlihat bahwa sig 0.226 atau $<0.05$, maka kesimpulan yang didapat ialah tidak ada perbedaan kemampuan yang signifikan antara hasil kemampuan kelompok kontrol dengan kelompok sampel pada test akhir. Artinya dengan menggunakan produk ini pemain bisa berlatih secara mandiri tanpa bimbingan pelatih karena memiliki dapak yang sama dan tidak ada perbedaan hasil yang signifikan.

\section{DAFTAR PUSTAKA}

Dwiyogo, W.D. 2008. Aplikasi Teknologi Pembelajaran Media Pembelajaran Penjas \& Olahraga. Malang: Fakultas Pendidikan Universitas Negeri Malang.

Koger, Robert. 2007. Latian Dasar Andal Sepak Bola Remaja. Klaten: PT Saka Mitra Kompetensi

Budiwanto, S .2004. Pengetahuan Dasar Melatih Olahraga. Malang: Jurusan Ilmu Keolahragaan FIP UM Universitas Negeri Malang

Wijayanto., \& Zuhri, M.S. 2014. Pengembangan E-Modul Berbasis Flip Book Maker dengan Model Project Based Learning untuk Mengembangkan Kemampuan Pemecahan Masalah Matematika. Prosiding Mathematics and Science Forum 2014, hlm 625-628.

Istiyanto. 2013. Pembuatan Media Ajar dengan Media Flip Book Maker. (Online), 
(http://istiyanto.com/pembuatan-mediaajar-dengan-flip-book-maker/), diakses 12 Juni 2016.

Rasiman. 2014. Efektivitas Resource - Based Learning Berbantuan Flip Book Maker dalam Pembelajaran Matematika SMA. JKPM. No 1 Vol 2, hlm 34-41.

Degeng, S. 2002. Metodologi Penelitian Pengembangan. Malang: Depdiknas Pusat Penelitian Pendidikan Universitas Negeri Malang 